Volume 5 Number 2, July-December 2021: pg. 107-120.

Fakultas Hukum, Universitas Lampung,

Bandar Lampung, Lampung, Indonesia.

E-ISSN: 2598-3105 P-ISSN: 2723-2581

http://jurnal.fh.unila.ac.id/index.php/cepalo

\title{
PRIMUM REMEDIUM ACTION SANCTIONS AGAINST CHILDREN IN CONFLICT WITH THE LAW
}

\section{Mashuril Anwar}

Faculty of Law, Universitas Lampung, Indonesia, E-mail: mashurilanwar97@gmail.com

Submitted: June 24, 2021; Reviewed: August 15, 2021; Accepted: October 8, 2021

DOI: $10.25041 /$ cepalo.v5no2.2362

\begin{abstract}
Criminal sanctions are more popular than action sanctions at the application level. Action sanctions formulation is regulated in Articles 82 and 83 of the Juvenile Criminal Justice System Law, while criminal sanctions are the last resort. However, criminal sanctions are still the "prima donna" in law enforcement practices against children in conflict. This condition raises various problems such as the overcapacity of correctional institutions, burdens the state budget, and creates a stigma against children in conflict with the law. Because the purpose of implementing the juvenile criminal justice system is in the child's best interests, action sanctions should be prioritised, even though criminal sanctions are needed in law enforcement against children in conflict with the law. Therefore, an idea emerged to restore criminal sanctions as ultimum remedium and strengthen action sanctions as primum remedium. The problem discussed in this study is how to implement primum remedium action sanctions against children in conflict with the law? And how to strengthen primum remedium action sanctions against children in conflict with the law? This study uses a normative juridical, an empirical juridical, and a comparative methods. The data in this article are sourced from primary and secondary data processed through description, prescription, and system. The results indicate that criminal sanctions still dominate judges' decisions in children in conflict with the law, and action sanctions are complementary sanctions because it is rarely applied.
\end{abstract}

Keywords: Children, Action Sanctions, Ultimum Remedium.

\section{A. Introduction}

Children presence in domestic life is a blessing for parents. ${ }^{1}$ Therefore, every child is obliged to protect of their dignity to become a valuable child. Child protection embodies justice that includes children's mental, social, and physical development. ${ }^{2}$ In addition, child

\footnotetext{
1 Febriana Annisa, "Penegakan Hukum Terhadap Anak Yang Melakukan Tindak Pidana Pencabulan Dalam Konsep Restoratif Justice," ADIL: Jurnal Ilmu Hukum 7, no. 2 (2016): 202-11, https://doi.org/10.33476/ajl.v7i2.355.

2 Maidin Gultom, Perlindungan Hukum Bagi Anak Dalam Sistem Peradilan Pidana Anak Di Indonesia (Bandung: PT Refika Aditama, 2008): 3.
} 
protection is needed because children are often faced with several conditions that force them to commit criminal acts in discovering their identity. ${ }^{3}$ Records from the General Judiciary Agency of the Supreme Court (Badilum MA) show that there were 22,730 juvenile criminal cases from 2015-2018 in the jurisdiction of the high court, with details as follows:

Graph 1. Children Cases in the High Court in 2015-2018

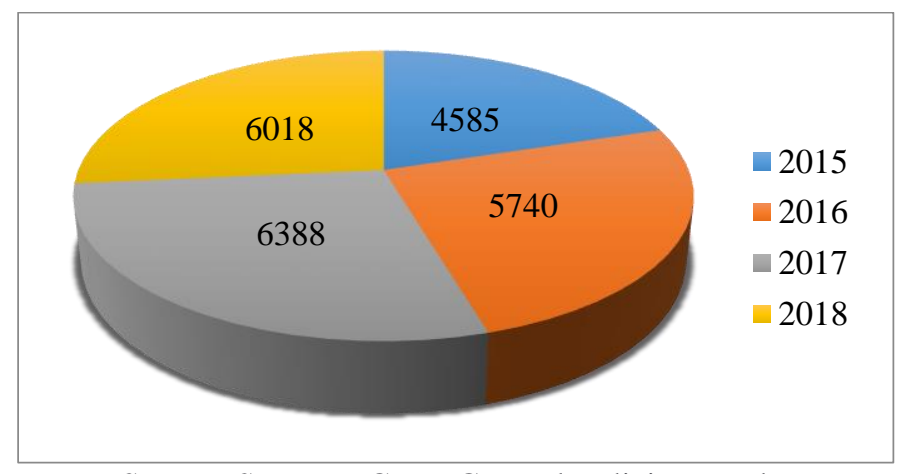

Source: Supreme Court General Judiciary Body

Based on graph 1 above, there were 4585 children cases in 2015, 5740 cases in 2016, 6388 cases in 2017, and 6018 cases in 2018. Indonesia has not resolved conventional problems such as criminal acts or legal conflicts committed by children. ${ }^{4}$ Lampung Province is one of the red zone areas with 309 child crime cases dominated by violence in 2019, as shown in the following graph:

Graph 2. Child Perpetrators of Violence by District/City in Lampung Province in 2019

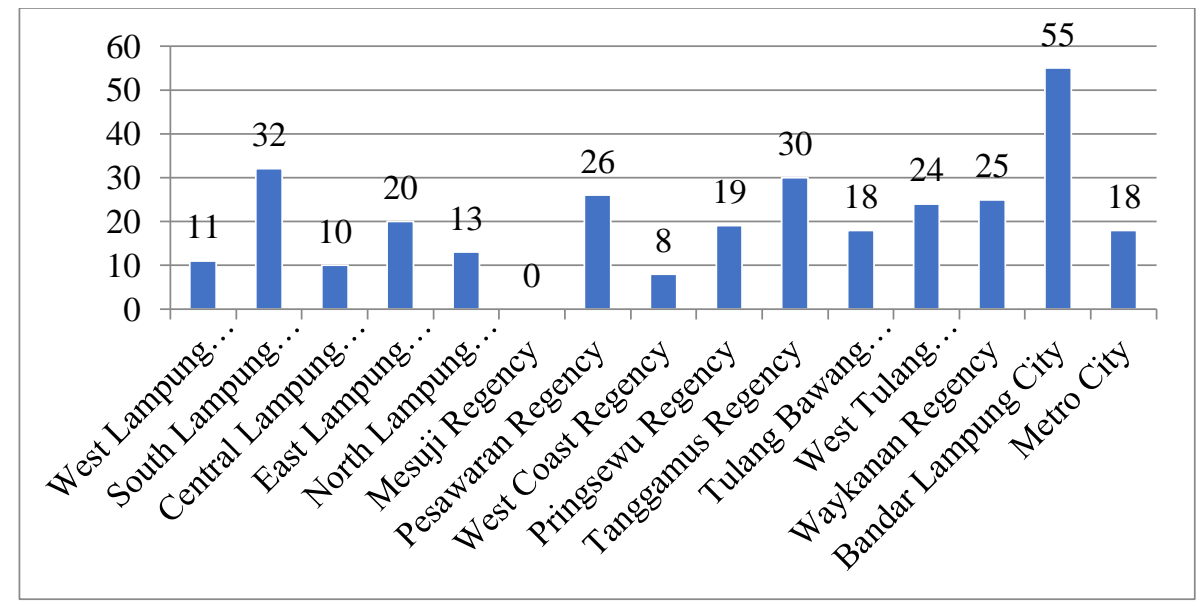

Source: Simponi PPA 2020

Based on graph 2, there are 11 child crime cases in West Lampung Regency, 32 cases in South Lampung Regency, 10 cases in Central Lampung Regency, 20 cases in East Lampung Regency, 13 cases in North Lampung Regency, no cases in Mesuji Regency, 26 cases in Pesawaran Regency, 8 cases in West Coast Regency, 19 cases in Pringsewu Regency, 30 cases in Tanggamus Regency, 18 cases in Tulang Bawang Regency, 24 cases in Tulang Bawang

\footnotetext{
${ }^{3}$ Mashuril Anwar and M. Ridho Wijaya, "Fungsionalisasi Dan Implikasin Asas Kepentingan Terbaik Bagi Anak Yang Berkonflik Dengan Hukum: Studi Putusan Pengadilan Tinggi Tanjung Karang," Undang: Jurnal Hukum 2, no. 2 (2019): 265-92, https://doi.org/10.22437/ujh.2.2.265-292.

${ }^{4}$ Hadi Supeno, Kriminalisasi Anak: Tawaran Gagasan Radikal Peradilan Anak Tanpa Pemidanaan (Jakarta: Gramedia Pustaka Utama, 2010): 2.
} 
Barat Regency, 25 cases in Way Kanan Regency, 55 cases in Bandar Lampung City, and 18 cases in Metro City.

Furthermore, 343 juvenile criminal cases are spread across eleven Lampung Province's District Courts, with 32 cases resolved through diversion. ${ }^{5}$ The low success of diversion causes children to be imprisoned and shows the blurry portrait of child protection in Indonesia. A prison is a familiar place for children to become experts in committing crimes. ${ }^{6}$ At the same time, child punishment provides a coaching purpose. ${ }^{7}$ Child punishment should consider the child's situation and proportionality principle. ${ }^{8}$ The punishment should be proportionate with the quality and quantity of their actions and should prioritise their best interests. ${ }^{9}$ Action sanctions are more prospectively applied to protect the children's best interests. Several legal instruments have regulated action sanctions for children in conflict with the law. ${ }^{10}$

The Criminal Code divides action sanctions into sanctions for people who could and could not take responsibility and reparation for criminal acts. ${ }^{11}$ Furthermore, actions sanctions for children in conflict with the law are regulated in Articles 82 and 83 of Law Number 11 of 2012 concerning the Juvenile Criminal Justice System (SPPA Law). The punishments in Article 82 are considered light and do not resolve the crime committed by the child. ${ }^{12}$ According to Article 82 paragraph (1) of the SPPA Law, the sanctions for children's actions, such as returning them to parents/guardians, handing them over to someone, treatment in a mental hospital, treatment in specific child development institutions, obligation to attend formal education and driving license revocation. The SPPA Law is considered the best legal instrument for protecting children in conflict with the law. However, at a practical level, the judge has the freedom to decide based on his belief and the evidence presented in court. ${ }^{13}$ So often, the judge's decision deviates from the procedural provisions. Judges' decisions in child cases are still dominated by imprisonment. This is evidenced by the Directorate General of Corrections data, which shows 11,334 criminal children in prisons between 2015-2019. ${ }^{14}$ This kind of law enforcement is unfair and detrimental to children because children who commit crimes should be given guidance, not retaliation.

In addition, the SPPA Law still has weaknesses. The SPPA Law implicitly oriented towards retaliation as punishment. ${ }^{15}$ Article 81 paragraph (5) the SPPA Law explicitly

\footnotetext{
52019 Annual Report High Court Tanjung Karang.

6 Kevin Walby, Justin Piché, and Bethany Friesen, ““...they Didn’t Just Do It Because It Was a Job”: Representing Wardens in Canadian Penal History Museums," International Journal of Law, Crime and Justice 53 (2018): 1-8, https://doi.org/10.1016/j.ijlcj.2017.12.002.

${ }^{7}$ Barda Nawari Arief, Bunga Rampai Kebijakan Hukum Pidana (Jakarta: PT Kencana Prenada Media Group, 2008): 98.

8 Lotem Perry-Hazan and Natali Lambrozo, "Young Children's Perceptions of Due Process in Schools' Disciplinary Procedures," British Educational Research Journal 44, no. 5 (2018): 827-846, https://doi.org/10.1002/berj.3469.

9 C. H. Adiputra L., R. B. Sularto, and A. M. Endah Sri Sulastuti, "Pelaksanaan Kebijakan Sanksi Tindakan Terhadap Anak Berkonflik Hukum Di Wilayah Kota Semarang,” Diponegoro Law Journal 7, no. 1 (2018): 4659.

${ }^{10}$ Ahmad Muhlis, Hukum Kawin Paksa Di Bawah Umur (Surabaya: CV Jakad Publishing, 2019): 75.

11 Gita Santika Ramadhani, Barda Nawari Arif, and Purwoto, "Sistem Pidana Dan Tindakan 'Double Track System' Dalam Hukum Pidana Indonesia,” Diponegoro Law Review 1, no. 4 (2012): 1-9.

${ }^{12}$ Henny Yuningsiha et al., "Ratio Legis of Chemical Castration to the Perpetrators of Sexual Violence against Children," Sriwijaya Law Review 4, no. 2 (2020): 285-303, https://doi.org/10.28946/slrev.Vol4.Iss2.652.pp285303.

13 Vivi Ariyanti, "Kebebasan Hakim Dan Kepastian Hukum Dalam Menangani Perkara Pidana Di Indonesia," Mahkamah: Jurnal Kajian Hukum Islam 4, no. 2 (2019): 162-74, https://doi.org/10.24235/mahkamah.v4i2.5374.

14 Correctional Database System, Directorate General of Corrections, Ministry of Law and Human Rights, Republic of Indonesia.

${ }^{15}$ Nikmah Rosidah, Asas-Asas Hukum Pidana (Semarang: Pustaka Magister, 2012): 46.
} 
stipulates that only imprisonment is the ultimum remedium for children in conflict with the law. Meanwhile, other criminal sanctions such as warnings, criminal conditions, job training, and coaching within the institution have not been declared ultimum remedium. This is what causes criminal sanctions are still the "prima donna". Meanwhile, action sanctions in the SPPA Law have not been declared as primum remedium sanctions. This is evident from the categorisation of the diversion application so that the prosecutor's demands are still dominated by criminal sanctions, as shown in the following graph:

Graph 3. Types of Claims in Child Cases

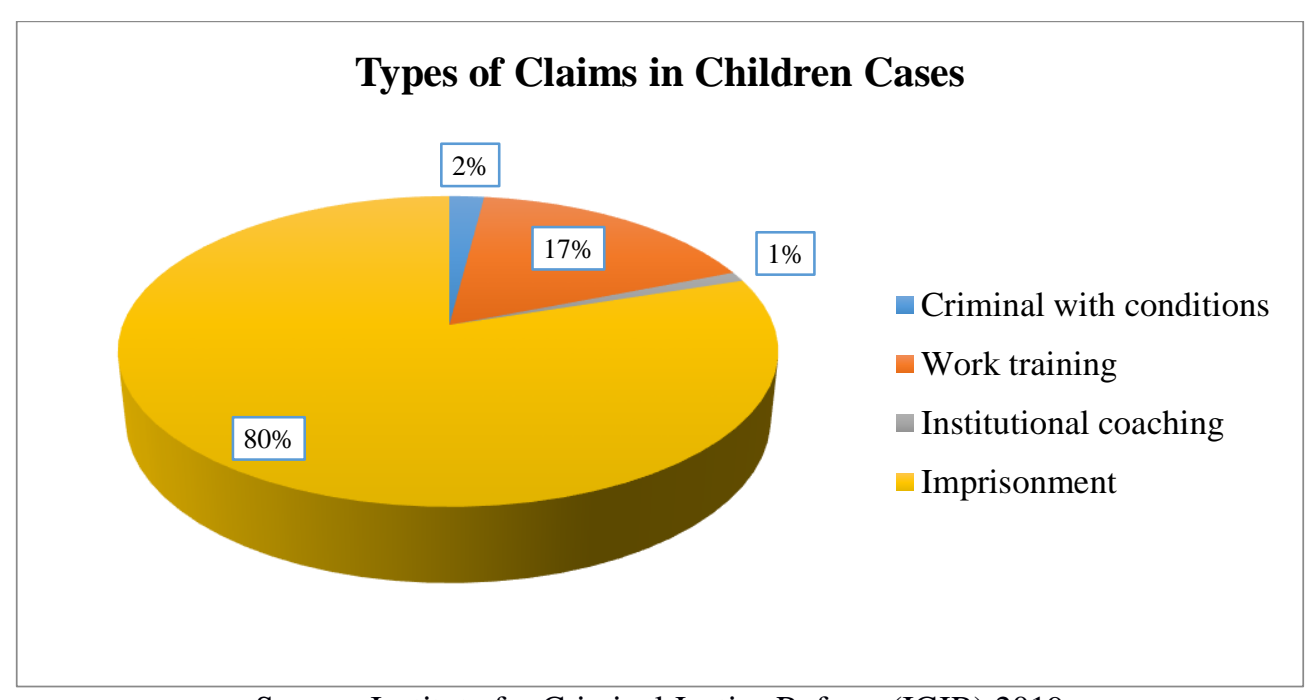

Source: Institute for Criminal Justice Reform (ICJR) 2019

Based on graph 3 , there are claims in child cases, including $2 \%$ criminal with conditions, $17 \%$ work training, $1 \%$ institutional coaching, and $80 \%$ imprisonment. This conditions are increasingly concerning when law enforcement in Indonesia is still positivistic-legalistic. Action sanctions are less popular than criminal sanctions and regarded as complementary sanctions, while criminal sanctions, especially prisons, are absolute. From 2015 to November 2020, there were 93 child cases sentenced to action sanctions and 1,597 child cases sentenced to imprisonment in eleven Lampung Province district courts, as shown in the graph below:

Graph 4. Action Sanctions in Eleven Lampung Province District Courts

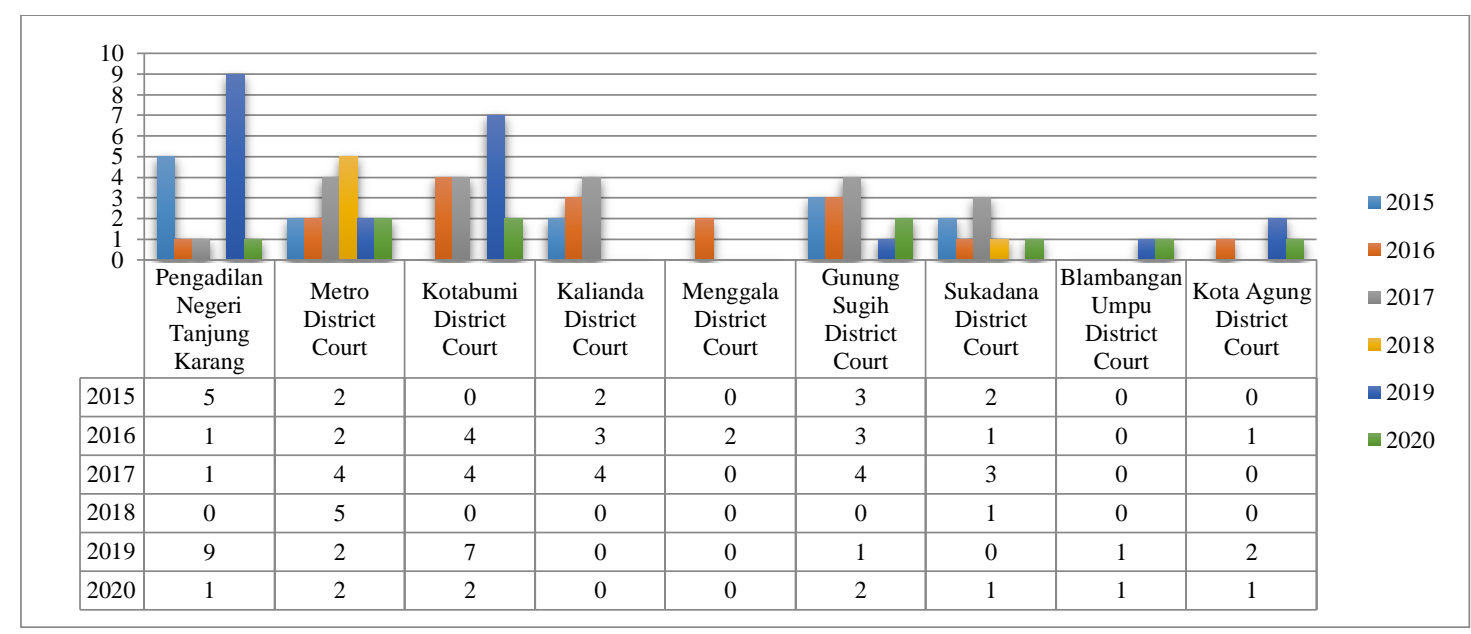

Source: Processed from the Case Investigation Information System of Each Court 
Based on graph 4, Tanjung Karang District Court has the most action sanctions from 2015 to 2020. Criminal sanctions should be used more selectively as a sanction that causes suffering. The jurists agree that criminal sanctions are used against extraordinary crimes that threaten public safety. Meanwhile, criminal sanctions should not be the primary sanctions for child crimes. This is because criminal sanctions would provide misery and bad stigma to children. Therefore, although criminal sanctions are needed to protect children, action sanctions should be prioritised. So to overcome the criminal sanctions weakness, an idea is needed to strengthen action sanctions as the primary sanction or primum remedium. ${ }^{16}$

The problems studied in this article are new from previous research. ${ }^{17}$ The ultimum remedium principle against children in conflict with the law protects children from the criminal justice system. The previous research description shows the research authenticity. The research has examined protection aspects for children in conflict with the law. Still, as discussed in this study, it has not yet reached the action sanctions aspect as a primum remedium for children in conflict with the law. The problem discussed in this study is how to implement primum remedium action sanctions against children in conflict with the law? And how to strengthen primum remedium action sanctions against children in conflict with the law?

This research uses normative juridical, empirical, and comparative approaches to answer the problems and achieve the objectives. The data in this article are sourced from primary and secondary data collected through literature study and interviews with five sources. The collected data is processed through description, prescription, and systematisation. The empirical juridical method analyses the implementation of primum remedium action sanctions against children in conflict with the law. Furthermore, normative juridical and comparative methods are used to analyse the strengthening of primum remedium actions sanctions against children in conflict with the law in the future.

\section{B. Discussion}

\section{Implementation of Primum Remedium Action Sanctions Against Children in Conflict with Current Law}

Children's punishment differs from that of adults. ${ }^{18}$ Considering that children are still emotionally and mentally immature, punishment should be made as light as possible and be a lesson for them. ${ }^{19}$ Based on restorative justice, action sanctions are more prospectively applied to children in conflict with the law. Action sanctions are in line with the objectives of the juvenile criminal justice system, namely protecting the child's best interests. Furthermore, action sanctions have several advantages compared to criminal sanctions. These advantages are preventing bad stigma against children, reducing the burden on correctional institutions and the state budget, potentially improving children's personalities, and recovering the consequences of criminal acts. Before explaining the action sanctions application further, the

\footnotetext{
16 Guntarto Widodo, "Sistem Pemidanaan Anak Sebagai Pelaku Tindak Pidana Perspektif Undang-Undang Nomor 11 Tahun 2012 Tentang Sistem Peradilam Pidana Anak,” Jurnal Surya Kencana Satu: Dinamika Masalah Hukum Dan Keadilan 6, no. 1 (2018): 59-82, https://doi.org/10.32493/jdmhkdmhk.v6i1.339.

17 According to research conducted by Beby Suryani Fithri, "Asas Ultimum Remedium Terhadap Anak Yang Berkonflik Dengan Hukum Dalam Rangka Perlindungan Anak," Mercatoria 10, no. 1 (2017): 74-88, https://doi.org/10.31289/mercatoria.v10i1.733.

18 Sri Endah Wahyuningsih, "The Implementation of Legal Protection against Children Who Commit Criminal Acts in the Judicial Process in Indonesia," International Journal of Psychosocial Rehabilitation 24, no. 8 (2020): 1097-1110, https://doi.org/10.37200/IJPR/V24I8/PR280121.

${ }^{19}$ Maulana Agus Salim, "Implementasi Sanksi Pidana Serta Tindakan Terhadap Anak Menurut Undang-Undang Nomor 11 Tahun 2012 Tentang Sistem Peradilan Pidana Anak,” Jurnal Sol Justicia 3, no. 1 (2020): 51-61, http://ojs.ukb.ac.id/index.php/sj/article/view/124.
} 
author describes the circumstances of child criminal cases in Lampung Province to provide a comprehensive understanding.

Table 1. Circumstances of Child Criminal Cases in Lampung Province's District Courts 2019

\begin{tabular}{|c|c|c|c|c|c|}
\hline Court Name & $\begin{array}{c}\text { Remaining } \\
\text { Case 2018 }\end{array}$ & $\begin{array}{c}\text { Entry } \\
\text { case }\end{array}$ & $\begin{array}{c}\text { Broken } \\
\text { Cases }\end{array}$ & $\begin{array}{c}\text { Remaining } \\
\text { Case 2019 }\end{array}$ & $\begin{array}{c}\text { Case } \\
\text { Resolution (\%) }\end{array}$ \\
\hline Tanjung Karang District Court & 0 & 93 & 93 & 0 & 100,00 \\
\hline Metro District Court & 1 & 17 & 18 & 0 & 100,00 \\
\hline Kotabumi District Court & 0 & 28 & 25 & 3 & 100,00 \\
\hline Kalianda District Court & 0 & 27 & 27 & 0 & 100,00 \\
\hline Liwa District Court & 0 & 15 & 14 & 1 & 93,33 \\
\hline Menggala District Court & 2 & 20 & 21 & 1 & 95,45 \\
\hline Gunung Sugih District Court & 0 & 33 & 33 & 0 & 100,00 \\
\hline Sukadana District Court & 0 & 30 & 30 & 0 & 100,00 \\
\hline Blambangan Umpu District Court & 0 & 20 & 20 & 0 & 100,00 \\
\hline Kota Agung District Court & 1 & 35 & 36 & 0 & 100,00 \\
\hline Gedong Tataan District Court & 0 & 14 & 13 & 1 & 93,00 \\
\hline Total & $\mathbf{4}$ & $\mathbf{3 3 2}$ & $\mathbf{3 3 0}$ & $\mathbf{6}$ & $\mathbf{9 9 7 , 2 3 4}$ \\
\hline
\end{tabular}

Source: Extracted from the Tanjung Karang High Court Annual Report

Based on table 1, child criminal cases in conflict with the law in eleven Lampung Province's district courts totalled 332 cases in 2019. There are 93 child criminal cases in the Tanjung Karang District Court, 17 cases in Metro District Court, 28 cases in Kotabumi District Court, 27 cases in Kalianda District Court, 15 cases in Liwa District Court, 20 cases in Menggala District Court, 33 cases in Gunung Sugih District Court, 30 cases in Sukadana District Court, 20 cases in Blambangan Umpu District Court, 35 cases in Kota Agung District Court, and 14 cases in Gedong Tataan District Court. In addition, child criminal cases are resolved by diversion so that they do not go to trial, as shown in the table below:

Table 2. Child Criminal Cases in Lampung Province's District Courts Settled Through Diversion

\begin{tabular}{|c|c|c|c|c|}
\hline District Court & $\begin{array}{c}\text { Number } \\
\text { of Child } \\
\text { Criminal } \\
\text { Cases }\end{array}$ & $\begin{array}{c}\text { Number } \\
\text { of } \\
\text { Diversion } \\
\text { Cases }\end{array}$ & $\begin{array}{c}\text { Number } \\
\text { of } \\
\text { Successful } \\
\text { Diversion } \\
\text { Cases }\end{array}$ & $\begin{array}{c}\text { Percentage } \\
\text { of } \\
\text { Successful } \\
\text { Diversion } \\
\text { Cases }\end{array}$ \\
\hline Tanjung Karang District Court & 93 & 22 & 22 & 100,00 \\
\hline Metro District Court & 18 & 1 & 0 & 0,00 \\
\hline Kotabumi District Court & 29 & 2 & 0 & 0,00 \\
\hline Kalianda District Court & 27 & 3 & 2 & 66,67 \\
\hline Liwa District Court & 20 & 0 & 0 & 0,00 \\
\hline Menggala District Court & 22 & 0 & 0 & 0,00 \\
\hline Gunung Sugih District Court & 33 & 33 & 1 & 3,03 \\
\hline Sukadana District Court & 30 & 14 & 0 & 0,00 \\
\hline Blambangan Umpu District Court & 20 & 2 & 2 & 10,00 \\
\hline Kota Agung District Court & 36 & 4 & 4 & 100,00 \\
\hline Gedong Tataan District Court & 14 & 1 & 1 & 100,00 \\
\hline TOTAL & $\mathbf{3 4 3}$ & $\mathbf{8 2}$ & $\mathbf{3 2}$ & $\mathbf{1 9 7 , 8 8}$ \\
\hline
\end{tabular}

Source: Extracted from the Tanjung Karang High Court Annual Report 
Based on table 2, there are 343 child criminal cases in eleven Lampung Province's District Courts, and 82 cases were attempted for diversion, but only 32 were successful. Thus, 50 juvenile criminal cases have not been successfully resolved by diversion, so they should go to trial. Furthermore, the following describes the types of judges' decisions in child criminal cases at eleven Lampung Province's district courts.

Table 3. Judges' Decisions on Child Criminal Cases in Lampung Province

\begin{tabular}{|c|c|c|c|c|}
\hline \multirow[b]{2}{*}{ District Court } & \multicolumn{2}{|c|}{ Judge's verdict } & \multirow{2}{*}{$\begin{array}{c}\text { Crime } \\
\text { and } \\
\text { Action }\end{array}$} & \multirow[b]{2}{*}{ Period } \\
\hline & $\begin{array}{l}\text { criminal } \\
\text { sanctions }\end{array}$ & $\begin{array}{c}\text { action } \\
\text { sanctions }\end{array}$ & & \\
\hline Tanjung Karang District Court & 403 & 21 & 1 & 2015-November 2020 \\
\hline Metro District Court & 49 & 17 & 1 & 2015-September 2020 \\
\hline Kotabumi District Court & 108 & 17 & 2 & 2015-October 2020 \\
\hline Kalianda District Court & 183 & 9 & 1 & 2015-October 2020 \\
\hline Liwa District Court & 41 & 0 & 0 & 2015-October 2020 \\
\hline Menggala District Court & 126 & 2 & 1 & 2015-October 2020 \\
\hline Gunung Sugih District Court & 161 & 13 & 1 & 2015-October 2020 \\
\hline Sukadana District Court & 217 & 8 & 1 & 2015-November 2020 \\
\hline Blambangan Umpu District Court & 106 & 2 & 0 & 2015-November 2020 \\
\hline Kota Agung District Court & 156 & 4 & 2 & 2015-November 2020 \\
\hline Gedong Tataan District Court & 47 & 0 & 0 & 2018-October 2020 \\
\hline TOTAL & 1.597 & 93 & 10 & \\
\hline
\end{tabular}

Source: Processed from the Case Investigation Information System (SIPP) of each Court

Responding to the data above, the Gedong Tataan District Court judge assessed that the SPPA Law had regulated action sanctions for children who committed criminal acts and applied to juvenile justice in Indonesia. ${ }^{20}$ Furthermore, according to a lecturer of the Criminal Law Department, Faculty of Law, University of Lampung, the regulation of action sanctions in the SPPA Law is unclear, so sanctions are rarely applied. ${ }^{21}$ This opinion aligns with table 3, which shows that criminal sanctions still dominate most judges' decisions and emphasise the action sanctions position as complementary sanctions.

Ideally, action sanctions and criminal sanctions are not equal. However, action sanctions should be prioritised. In addition, the punishment of children in conflict with the law should consider the consequences, the needs and characteristics of the child. ${ }^{22}$ The constitution mandate that every child has the right to survival, normal growth, and protection. ${ }^{23}$ Furthermore, based on the convention on children's rights, children's rights are generally divided into four categories: survival rights, protection rights, participate rights, grow and develop rights. ${ }^{24}$ Meanwhile, in Criminal Code (KUHP), a person could be held criminally responsible if that person has self-awareness. If a child commits a crime, the judge should consider the act's background to prioritise the action sanctions in adjudicating. ${ }^{25}$

\footnotetext{
${ }^{20}$ Interview with Gedong Tataan District Court Judge on 2 December 2020.

${ }^{21}$ Interview with Lecturer of Criminal Law Department, Faculty of Law, Universitas Lampung on 7 December 2020.

${ }^{22}$ Anggoro Wicaksono, "Sanksi Tindakan Sebagai Sarana Alternatif Penanggulangan Kejahatan Psikotropika Anak Bagi Pecandu Dan Pelaku Anak Dalam Perspektif Hukum Pidana,” USU Law Journal 3, no. 1 (2015): 2034, http://repositori.usu.ac.id/handle/123456789/38918.

${ }^{23}$ See Article 28B Paragraph (2) of the 1945 Constitution of the Republic of Indonesia.

${ }^{24}$ Mohammad Joni and Zulchaina Z. Tanamas, Aspek Hukum Perlindungan Anak Dalam Perspektif Konvensi Hak Anak (Bandung: Citra Aditya Bakti, 1999): 35.

${ }^{25}$ M. Nasir Djamil, Anak Bukan Untuk Dihukum (Jakarta: Sinar Grafika, 2013): 34.
} 
Based on table 3, action sanctions are less popular than criminal sanctions. In practice, criminal sanctions dominate juvenile criminal justice. Based on the identification of eleven Lampung Province's district courts decisions, 506 cases of children in conflict with the law were sentenced to imprisonment, and 32 cases were sentenced to action sanctions. Theft, narcotics, threats, traffic violations, and criminal acts involving firearms and sharp weapons dominated the 32 cases sentenced to action sanctions.

Action sanctions are imposed by returning to parents and submission to the state. In addition to the judges' legal culture who emphasise criminal sanctions (imprisonment), the widespread sanctions are due to the juvenile criminal justice system's sanctions system ignoring the basic principles of child protection, namely the child's best interests. The juvenile criminal justice system formulation policy has adopted the child's best interests principle by regulating action sanctions. However, action sanctions formulation is not yet primum remedium or the primary sanctions. Consequently, action sanctions application against children in conflict with the law is not optimal and seems to complement criminal sanctions.

\section{Strengthening of Primum Remedium Action Sanctions Against Children in Conflict with the Law}

According to The Beijing Rules or the Convention on the Child's Rights, the juvenile criminal justice system is child welfare-oriented. Furthermore, item 5 of The Beijing Rules emphasises that sanctions for deprivation of liberty are a last resort and imposed as lightly as possible. Indonesia should use The Beijing Rules to formulate juvenile criminal justice system policies as a ratifying country. In addition, based on the child's best interests principle as regulated by The Beijing Rules, a judge's decision in Indonesia that imposes a criminal of independence confiscation and/or restriction should be the last resort. ${ }^{26}$ However, law enforcement against children in conflict with the law in Indonesia has not fully implemented the child's best interests principle. In law enforcement, judges have not optimally explored the children background who commit crimes to neglect their rights. ${ }^{27}$

The judge sentenced a child defendant to six years in prison for theft with violence that caused a death in decision Number: 05/Pid/2014/PT.TJK. In the decision, there was no judge's consideration regarding the child defendant's condition, who is still young and wants to continue their education. The judge also did not consider the child's best interests principle as mandated by Article 2 letter d of the SPPA Law. Therefore, the judge believes that light punishment would not deter children.

Furthermore, the judge sentenced the child defendant (16) to one year in prison in decision Number: 20/Pid/2012/PT.TJK because it was proven that he had no right to control narcotics class I. The judge looked in a casuistic manner and had considered the child's best interests and restorative justice. However, the positivism paradigm still shackles judges to impose criminal liberty deprivation in the form of imprisonment. The judge disregarded the child's right to medical and social rehabilitation. These two cases show that the judge's considerations in deciding cases involving children in conflict with the law are based on juridical provisions. The judge has not explored the non-juridical provisions that children are

\footnotetext{
26 Binsar M. Gultom, Pandangan Kritis Seorang Hakim Dalam Penegakan Hukum Di Indonesia (Jakarta: Gramedia Pustaka Utama, 2012): 93.

${ }^{27}$ Bismar Siregar et al., Hukum Dan Hak-Hak Anak (Jakarta: Rajawali, 1986): 26.
} 
the next generation who still have constraints compared to adults. ${ }^{28}$ Therefore, children should be protected from adverse conditions in criminal justice. ${ }^{29}$

The description above shows the reformulation urgency of primum remedium action sanctions against children in conflict with the law. Action sanctions could be recovering the consequences of the criminal acts, facilitating the integration process into society, preventing negative stigma against children and liberty deprivation. Based on the study and analysis of the SPPA Law, several juvenile crimes should be subject to action sanctions in the ius constituendum of the juvenile criminal justice system. These actions include the action sanctions designation for children, the action sanctions form, the minimum and maximum limits of action sanctions, and the addition of norms that require judges to prioritise action sanctions against children in conflict with the law.

In principle, reformulating action sanctions as a primum remedium sanction does not eliminate the child's guilt for being held criminally responsible. The classification of children's actions that should be subject to action sanctions emphasises efforts to improve the child's personality and consequences. The suggestions for action sanctions reformulation to be included in the ius constituendum of the juvenile criminal justice system are described in the table below:

Table 4. Strengthening Action Sanctions for Primum Remedium against Children in Conflict with the Law in the SPPA Law

\begin{tabular}{|c|c|c|c|}
\hline Number & Ius Constituendum & $\begin{array}{c}\text { Nature of } \\
\text { Action } \\
\text { Sanctions }\end{array}$ & $\begin{array}{c}\text { Nature of } \\
\text { Criminal } \\
\text { Sanctions }\end{array}$ \\
\hline 1. & $\begin{array}{l}\text { Article } 3 \\
\text { (1) The provisions of the legislation impose an action } \\
\text { sanction } \\
\text { (2) Criminal sanctions may be imposed concurrently with } \\
\text { action sanctions }\end{array}$ & - & - \\
\hline 2. & $\begin{array}{l}\text { Article } 17 \\
\text { (1) Investigators, Public Prosecutors, and Judges are } \\
\text { obligated to prioritise action sanctions for children } \\
\text { being examined for criminal acts committed in } \\
\text { emergencies and/or against their will. } \\
\text { (2) As mentioned in paragraph (1), the action sanctions } \\
\text { shall be implemented directly and not gradually. }\end{array}$ & $\begin{array}{c}\text { Primum } \\
\text { Remedium }\end{array}$ & $\begin{array}{c}\text { Ultimum } \\
\text { Remedium }\end{array}$ \\
\hline 3. & $\begin{array}{l}\text { Article } 18 \\
\text { (1) In handling cases of children in conflict with the law, } \\
\text { Social Advisors, Professional Social Workers, and } \\
\text { Social Welfare Workers, Investigators, Public } \\
\text { Prosecutors, Judges, and Advocates, or other legal aid } \\
\text { providers should pay attention to the best interests of } \\
\text { the child and seek action sanctions for the child. } \\
\text { (2) As mentioned in paragraph (1), the exploitation of } \\
\text { action sanctions is based on research on children in } \\
\text { conflict with the law. } \\
\text { (3) Criminal sanctions may be imposed on children based } \\
\text { on the research results. Children in conflict with the } \\
\text { law should not be subject to action sanctions. }\end{array}$ & $\begin{array}{c}\text { Primum } \\
\text { Remedium }\end{array}$ & $\begin{array}{c}\text { Ultimum } \\
\text { Remedium }\end{array}$ \\
\hline
\end{tabular}

28 Kamaruddin Jafar, "Restorative Justice Atas Diversi Dalam Penanganan Juvenile Deliquency (Anak Berkonflik Dengan Hukum)," Jurnal Al'Adl 8, no. 2 (2018): 81-101, https://doi.org/10.31332/aladl.v8i2.361.

${ }^{29}$ Suparmin, "Kebijakan Hukum Pidana Dalam Tindak Pidana Yang Dilakukan Anak," Qistie: Jurnal Ilmu Hukum $1, \quad$ no. $\quad 1 \quad$ (2008): $1-12$, https://publikasiilmiah.unwahas.ac.id/index.php/QISTIE/article/download/877/1404. 


\begin{tabular}{|c|c|c|c|}
\hline 4. & $\begin{array}{l}\text { Article } 21 \\
\text { Every child who commits a criminal act should seek } \\
\text { sanctions for action in advance regardless of the age } \\
\text { limit. }\end{array}$ & $\begin{array}{l}\text { Primum } \\
\text { Remedium }\end{array}$ & Decriminalization \\
\hline 5. & $\begin{array}{l}\text { Article } 69 \text { paragraph (2) } \\
\text { (1) Every child who commits a criminal act could only be } \\
\text { subject to action sanctions. } \\
\text { (2) Criminal sanctions could only be imposed on children } \\
\text { if a child's crime has a high risk of public safety and } \\
\text { order, threatens national security, and the child's } \\
\text { actions involve the state's sovereignty. }\end{array}$ & $\begin{array}{c}\text { Primum } \\
\text { Remedium }\end{array}$ & $\begin{array}{c}\text { Ultimum } \\
\text { Remedium }\end{array}$ \\
\hline 6. & $\begin{array}{l}\text { Article } 70 \\
\text { (1) In imposing sanctions for action, the judge is obliged } \\
\text { to consider the severity of the act, the child's condition, } \\
\text { and the losses caused by the criminal act committed by } \\
\text { the child. } \\
\text { (2) Children could only be subject to criminal sanctions if, } \\
\text { according to the judge's assessment based on the } \\
\text { considerations referred to in paragraph (1), the child } \\
\text { could no longer be fostered. }\end{array}$ & $\begin{array}{c}\text { Primum } \\
\text { Remedium }\end{array}$ & $\begin{array}{c}\text { Ultimum } \\
\text { Remedium }\end{array}$ \\
\hline 7. & $\begin{array}{l}\text { Article } 71 \text { paragraph (1) } \\
\text { In the case of a child committing a criminal act in a } \\
\text { violation and a minor crime, the child is subject to action } \\
\text { sanctions as a substitute for the primary crime. }\end{array}$ & $\begin{array}{l}\text { Primum } \\
\text { Remedium }\end{array}$ & - \\
\hline 8. & $\begin{array}{l}\text { Article } 82 \text { paragraph (1) } \\
\text { (1) The judge is obliged to impose sanctions if a criminal } \\
\text { act committed by a child is a criminal offence, a minor } \\
\text { crime, a victimless crime, and the value of the loss } \\
\text { incurred is below the provincial minimum wage. } \\
\text { (2) Action sanctions that may be imposed on children } \\
\text { include: } \\
\text { a. Rebuke; } \\
\text { b. Return to parent/guardian; } \\
\text { c. Submission to someone; } \\
\text { d. Treatment in a Mental Hospital; } \\
\text { e. Placement in an orphanage; } \\
\text { f. Placement in educational institutions; } \\
\text { g. Placement in Child Special Guidance } \\
\text { h. Onstitutions; } \\
\text { i. Rbligation to attend education and/or training } \\
\text { j. Providing compensation to victims; } \\
\text { k. The obligation to repair the consequences caused } \\
\text { l. Dy criminal acts; } \\
\text { m. Reprivation of profits derived from criminal acts; } \\
\text { (3) As mentioned in paragraph (2), the action sanctions } \\
\text { could be imposed directly without stages. } \\
\text { (4) Children may be subject to criminal sanctions if their } \\
\text { actions do not meet the qualifications as mentioned in } \\
\text { paragraph (1), and/or the child does not fulfil their } \\
\text { obligations as referred to in paragraph (2) letters j, } 1 \text {, } \\
\text { and m. } \\
\text { Based on his assessment, if a child is subject to } \\
\text { sanctions as referred to in paragraph } 2 \text { letters d, e, f, g, } \\
\text { and h, the judge may impose part or all of the costs on }\end{array}$ & $\begin{array}{l}\text { Primum } \\
\text { Remedium }\end{array}$ & $\begin{array}{l}\text { Ultimum } \\
\text { Remedium }\end{array}$ \\
\hline
\end{tabular}




\begin{tabular}{|c|c|c|}
\hline \multicolumn{3}{|l|}{$\begin{array}{l}\text { the child's parents, who are the perpetrators the crime. } \\
\text { 6) As referred to in paragraph } 5 \text {, the judge's assessment is } \\
\text { in the form of the financial ability of the child's } \\
\text { parents, who are the perpetrators of the crime. }\end{array}$} \\
\hline Article 82 paragraph (2) & & \\
\hline $\begin{array}{l}\text { 1) Action sanctions are imposed on children for a } \\
\text { minimum of } 1 \text { year and could be extended for a } \\
\text { maximum of } 3 \text { months. } \\
\text { 2) If the child is subject to action sanctions in the form of } \\
\text { returning }\end{array}$ & - & - \\
\hline $\begin{array}{l}\text { Article } 82 \text { paragraph }(3) \\
\text { The public prosecutor, in their demands, should submit } \\
\text { sanctions against children who commit criminal acts. }\end{array}$ & $\begin{array}{c}\text { Primum } \\
\text { Remedium }\end{array}$ & $\begin{array}{c}\text { Ultimum } \\
\text { Remedium }\end{array}$ \\
\hline
\end{tabular}

The actions sanctions concept above should be followed up by revising the SPPA Law. In addition, according to the provisions of Article 82 paragraph (4) of the SPPA Law, action sanctions should be regulated in a Government Regulation concerning the imposition and implementation of action sanctions for children in conflict with the law.

\section{Conclusion}

In practice, action sanctions are still very rarely applied. Criminal sanctions still dominate judge's decisions in child cases. Ideally, action sanctions should be prioritised and implemented. Action sanctions are more prospective to be used as the primary sanctions or primum remedium for children who conflict with the law. Action sanctions are more potential in recovering the consequences of criminal acts, preventing children from negative stigma, reducing the burden on the State budget and the correctional institutions capacity. The strengthening action sanctions scope is primum remedium against children in conflict with the law (ius constituendum). This scope is related to the action sanctions determination, action sanctions form, the imposition period action sanctions, and norms that stipulate the judges' obligation to prioritise action sanctions in deciding children in conflict with the law cases.

\section{REFERENCES}

Adiputra L., C. H., R. B. Sularto, and A. M. Endah Sri Sulastuti. "Pelaksanaan Kebijakan Sanksi Tindakan Terhadap Anak Berkonflik Hukum Di Wilayah Kota Semarang." Diponegoro Law Journal 7, no. 1 (2018): 46-59.

Annisa, Febriana. "Penegakan Hukum Terhadap Anak Yang Melakukan Tindak Pidana Pencabulan Dalam Konsep Restoratif Justice." ADIL: Jurnal Ilmu Hukum 7, no. 2 (2016): 202-11. https://doi.org/10.33476/ajl.v7i2.355.

Anwar, Mashuril, and M. Ridho Wijaya. "Fungsionalisasi Dan Implikasin Asas Kepentingan Terbaik Bagi Anak Yang Berkonflik Dengan Hukum: Studi Putusan Pengadilan Tinggi Tanjung Karang." Undang: Jurnal Hukum 2, no. 2 (2019): 265-92. https://doi.org/10.22437/ujh.2.2.265-292.

Arief, Barda Nawari. Bunga Rampai Kebijakan Hukum Pidana. Jakarta: PT Kencana Prenada Media Group, 2008: 98.

Ariyanti, Vivi. "Kebebasan Hakim Dan Kepastian Hukum Dalam Menangani Perkara Pidana Di Indonesia." Mahkamah: Jurnal Kajian Hukum Islam 4, no. 2 (2019): 162-74. https://doi.org/10.24235/mahkamah.v4i2.5374. 
Djamil, M. Nasir. Anak Bukan Untuk Dihukum. Jakarta: Sinar Grafika, 2013: 34.

Fithri, Beby Suryani. "Asas Ultimum Remedium Terhadap Anak Yang Berkonflik Dengan Hukum Dalam Rangka Perlindungan Anak." Mercatoria 10, no. 1 (2017): 74-88. https://doi.org/10.31289/mercatoria.v10i1.733.

Gultom, Binsar M. Pandangan Kritis Seorang Hakim Dalam Penegakan Hukum Di Indonesia. Jakarta: Gramedia Pustaka Utama, 2012: 93.

Gultom, Maidin. Perlindungan Hukum Bagi Anak Dalam Sistem Peradilan Pidana Anak Di Indonesia. Bandung: PT Refika Aditama, 2008: 3.

Jafar, Kamaruddin. "Restorative Justice Atas Diversi Dalam Penanganan Juvenile Deliquency (Anak Berkonflik Dengan Hukum)." Jurnal Al'Adl 8, no. 2 (2018): 81-101. https://doi.org/10.31332/aladl.v8i2.361.

Joni, Mohammad, and Zulchaina Z. Tanamas. Aspek Hukum Perlindungan Anak Dalam Perspektif Konvensi Hak Anak. Bandung: Citra Aditya Bakti, 1999: 35.

Muhlis, Ahmad. Hukum Kawin Paksa Di Bawah Umur. Surabaya: CV Jakad Publishing, 2019: 75.

Perry-Hazan, Lotem, and Natali Lambrozo. "Young Children's Perceptions of Due Process in Schools' Disciplinary Procedures." British Educational Research Journal 44, no. 5 (2018): 827-846. https://doi.org/10.1002/berj.3469.

Ramadhani, Gita Santika, Barda Nawari Arif, and Purwoto. "Sistem Pidana Dan Tindakan 'Double Track System' Dalam Hukum Pidana Indonesia." Diponegoro Law Review 1, no. 4 (2012): 1-9.

Rosidah, Nikmah. Asas-Asas Hukum Pidana. Semarang: Pustaka Magister, 2012: 46.

Salim, Maulana Agus. "Implementasi Sanksi Pidana Serta Tindakan Terhadap Anak Menurut Undang-Undang Nomor 11 Tahun 2012 Tentang Sistem Peradilan Pidana Anak." Jurnal Sol Justicia 3, no. 1 (2020): 51-61. http://ojs.ukb.ac.id/index.php/sj/article/view/124.

Siregar, Bismar, Abdul Hakim G. Nusantara, Suwantji Sisworahardjo, Arif Gosita, and Mulyana W. Kusumah. Hukum Dan Hak-Hak Anak. Jakarta: Rajawali, 1986: 26.

Suparmin. "Kebijakan Hukum Pidana Dalam Tindak Pidana Yang Dilakukan Anak." Qistie: $\begin{array}{llllll}\text { Jurnal Ilmu Hukum 1, no. } 1 \text { 12. } & \text { (2008): }\end{array}$ https://publikasiilmiah.unwahas.ac.id/index.php/QISTIE/article/download/877/1404.

Supeno, Hadi. Kriminalisasi Anak: Tawaran Gagasan Radikal Peradilan Anak Tanpa Pemidanaan. Jakarta: Gramedia Pustaka Utama, 2010: 2.

Wahyuningsih, Sri Endah. "The Implementation of Legal Protection against Children Who Commit Criminal Acts in the Judicial Process in Indonesia." International Journal of Psychosocial Rehabilitation 24, no. 8 (2020): 1097-1110. https://doi.org/10.37200/IJPR/V24I8/PR280121.

Walby, Kevin, Justin Piché, and Bethany Friesen. ““...they Didn’t Just Do It Because It Was a Job': Representing Wardens in Canadian Penal History Museums.” International Journal of Law, Crime and Justice 53 (2018): 1-8. https://doi.org/10.1016/j.ijlcj.2017.12.002. 
Wicaksono, Anggoro. "Sanksi Tindakan Sebagai Sarana Alternatif Penanggulangan Kejahatan Psikotropika Anak Bagi Pecandu Dan Pelaku Anak Dalam Perspektif Hukum Pidana." $\begin{array}{lllllll}\text { USU Law } & \text { Journal 20-34. }\end{array}$ http://repositori.usu.ac.id/handle/123456789/38918.

Widodo, Guntarto. "Sistem Pemidanaan Anak Sebagai Pelaku Tindak Pidana Perspektif Undang-Undang Nomor 11 Tahun 2012 Tentang Sistem Peradilam Pidana Anak." Jurnal Surya Kencana Satu: Dinamika Masalah Hukum Dan Keadilan 6, no. 1 (2018): 59-82. https://doi.org/10.32493/jdmhkdmhk.v6i1.339.

Yuningsiha, Henny, I Nyoman Nurjayab, Prija Djatmikab, and Masruchin Ruba'I. "Ratio Legis of Chemical Castration to the Perpetrators of Sexual Violence against Children." Sriwijaya Law Review 4, no. 2 (2020): 285-303. https://doi.org/10.28946/slrev.Vol4.Iss2.652.pp285-303. 
